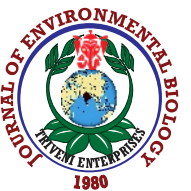

\title{
Phytotherapy in aquaculture: Integration of endogenous application with science
}

\author{
C.M. Chong ${ }^{1 *}$, A.V.S. Ganaseh Murthy', C.Y. Choy ${ }^{2}$ and K. S. Lai ${ }^{3}$ \\ ${ }^{1}$ Laboratory of Marine Biotechnology, Institute of Bioscience, Universiti Putra Malaysia, 43400 UPM Serdang, Selangor, Malaysia \\ ${ }^{2}$ Perdana University PURCSI School of Medicine, MAEPS Building, MARDI Complex, Jalan MAEPS Perdana,43400 Serdang, Selangor, Malaysia \\ ${ }^{3}$ Health Sciences Division, Abu Dhabi Women's College, Higher Colleges of Technology, 41012 Abu Dhabi, United Arab Emirates \\ *Corresponding Author Email : choumin@upm.edu.my
}

\begin{abstract}
Aquaculture is a growing industry that contributes about half of the global fish production. However, the production growth of this industry is restricted by many factors and challenges amongst which, infectious disease plays a major role. Some of the convenient and common practices to mitigate diseases in aquaculture are through the use of antibiotics and chemical disease-control agents. These practices, although well-meaning pose tremendous public and environmental health concerns. An alternative approach is via the use of medicinal plants, though this has been practised as an endogenous application to treat or prevent diseases. This biodegradable and environmental-friendly application is known as phytotherapy, or more often commonly called herbalism. Hence, this review article will emphasise on phytotherapy as an alternative treatment for disease in aquaculture and its role in aquaculture. Common diseases threatening aquaculture and the corresponding clinical signs are also discussed in this review. In addition, the mode of action, major classes and side effects of antibiotics are also highlighted. Finally, this review addresses current issues and prospects of phytotherapeutic application in aquaculture.
\end{abstract}

Keywords: AMR, Antibiotics, Aquaculture, Immunoprophylactics, Phytotherapy
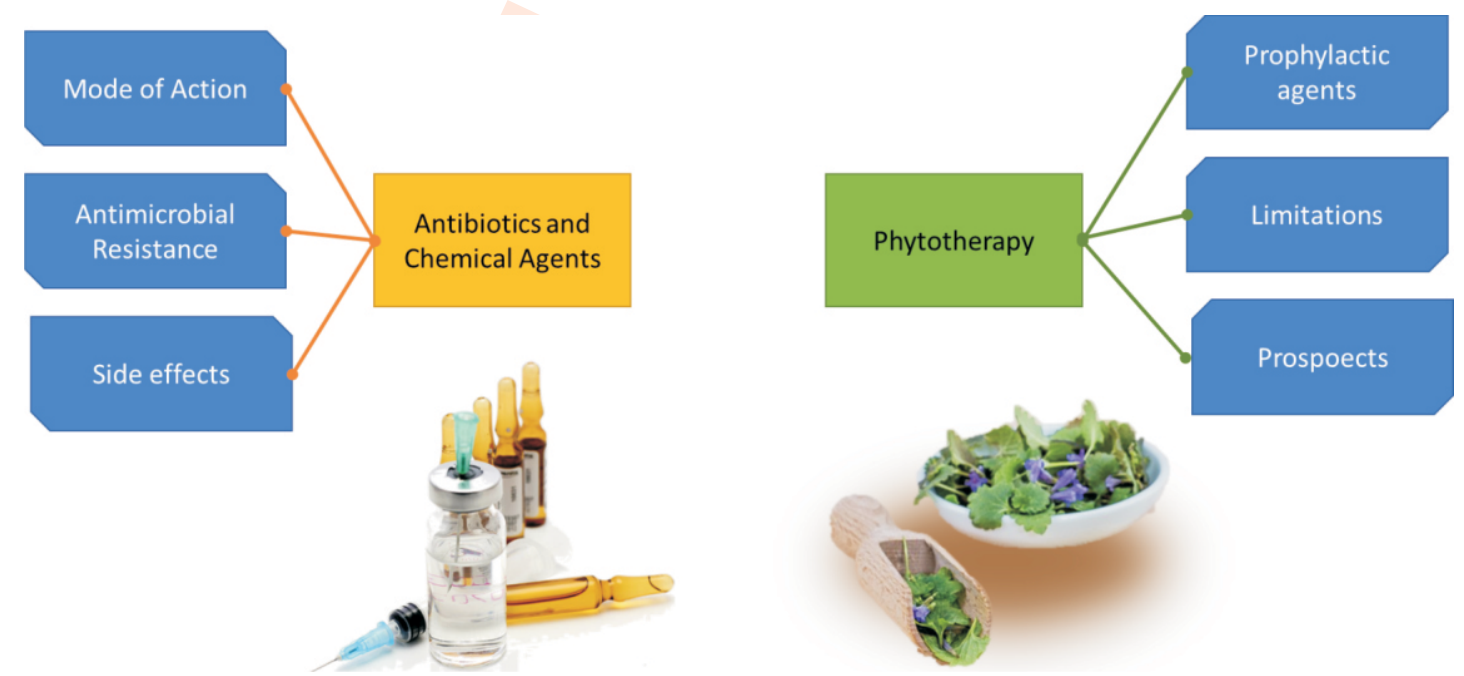

How to cite : Chong, C.M., A.V.S. Ganaseh Murthy, C.Y. Choy and K.S. Lai: Phytotherapy in aquaculture: Integration of endogenous application with science. J. Environ. Biol., 41, 1204-1214 (2020). 


\section{Introduction}

Aquaculture is a system which uses various methods and techniques to cultivate aquatic organisms, this involves the action of farming aquatic species ranging from freshwater to saltwater. According to the Food and Agriculture Organization of the United Nations (FAO, 2019), aquaculture is a booming industry representing $46 \%$ of the total global fish production (about 172.6 million tonnes) worth of USD 238 billion in 2017. The average annual increase in global fish consumption (3.2 percent) exceeded that of meat produced from all terrestrial animals combined (2.8 percent) between 1961 and 2016 (FAO, 2018). Furthermore, fish accounted for about $20 \%$ of animal protein consumed by humans globally (FAO, 2019). This massive global demand for fish was supplied mainly by aquaculture as captured fishery failed to expand since the late 1980s (FAO, 2018).

However, the production growth of this industry is restricted by several factors and challenges, amongst which infectious disease plays a major role. The outbreak of disease is often due to poor fish health management, such as poor water quality, nutrition and sanitation as well as high stocking intensity. Infectious disease has a negative impact on the industry which caused a loss of over USD 6 billion per annum in the global aquaculture industry according to FAO (Brummett et al., 2014). This great financial loss has altered the supply and demand for food fish but has also devastated the livelihood of fish farmers, resulting in increased rate of unemployment and a decrease in their main income.

To overcome this constraint, appropriate treatments and techniques to control the diseases, which are scientifically proven to be effective, have to be applied. For years, many different culture techniques (Dauda et al., 2018) and types of treatment such as administering antibiotics, vaccines, probiotics, prebiotics, dietary supplements and medicinal plants have been used to control many diseases in the aquaculture sector (Assefa and Abunna, 2018; Chong and Maha, 2014; Ebrahimi et al., 2017; Masduki et al., 2018; Romano et al., 2016; Romano et al., 2018). The use of medicinal plants to treat or prevent disease is known as phytotherapy and often commonly called herbalism (Falzon and Balabanova, 2017). This review article emphasises on phytotherapy as an alternative treatment for disease in aquaculture and its role in aquaculture.

Types of common fish diseases: A fish disease occurs through the interaction between the fish (host), pathogen and its environment which often results in the presentation of certain signs unique to the disease (Said et al., 2018). The mechanics of these three variables (Fig. 1) have to be studied and understood well so that measures can be taken to prevent and restrict the disease. Disease causing pathogens that give rise to infections in fish can be classified into fungal, protozoan, bacterial and viral.

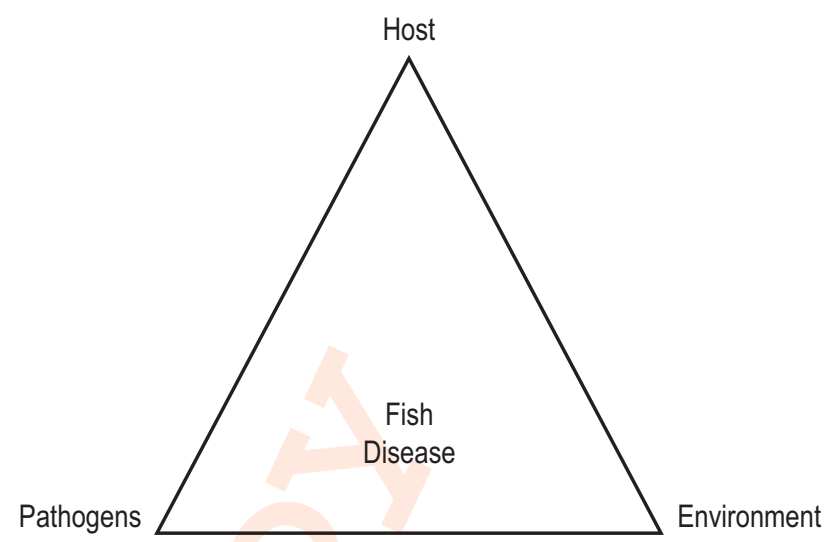

Fig. 1 : Interaction between host, pathogen and environment resulting in disease.

Table 1 summarises common pathogenic diseases in aquaculture.

Use of antibiotics and chemical disease-control agents: Bacterial infections are the most common and play a major role in limiting aquaculture production. While vaccination remains a fascinating approach in prevention of bacterial disease, the functional immunology knowledge of many tropical fish species is still in it's infancy. This constraint has hindering the development of effective vaccines in these species (Chong and Low, 2019). Hence, antibiotics are used to control these infections and are often given prophylactically. This leads to a growing risk of bacteria evolving into antibiotic resistant strains resulting in superbugs which will be extremely difficult to treat (Chong et al., 2019: Moo et al., 2019). In some cases, bacterial diseases can no longer be treated with antibiotics. A report by Karunasagar et al. (1994) showed mass mortality in Penaeus monodon larvae caused by Vibrio harveyi having strains resistant to cotrimoxazole, chloramphenicol, erythromycin and streptomycin. Note that cotrimoxazole and chloramphenicol have often been used as prophylactics (Defoirdt et al., 2011; Karunasagar et al., 1994). The major classes of antibiotics used in the aquaculture sector and their coressponding mode of action against pathogens is shown in Table 2.

Aside from increasing the risk of developing multi resistant strains of bacteria, excessive use of antibiotics results in the presence of residual antibiotics in commercialised fish and shellfish products (Cabello et al., 2011; Mahizan et al., 2019). This leads to undetected consumption of antibiotics in fish consumers which may cause antibiotic allergies and toxicities (Bassetti et al., 2019). These allergies and toxicities may also develop in unprotected workers working in the aquaculture sector through contact with large amount of antibiotics on skin, intestinal and bronchial tracts. Hence, novel strategies that cause less harm and risks have to be used to target pathogens that lead to disease and infection in aquaculture. 
Like any other animal, fishes are prone to different diseases such as parasitic infection, bacterial infections and viral infection. Several significant cases of fish disease that resulted in high mortality has been documented around the globe. Example of a reported case occurred in 1995 and 1998-1999 when Pilchard herpesvirus caused a high epizootic mortality in Australia (Whittington et al., 2008). Such situation further proved that fish living in the wild or reared in fish farms are susceptible to

Table 1: Overview of common fish diseases caused by different classes of pathogenic microorganisms

\begin{tabular}{|c|c|c|c|}
\hline Pathogens & & Diseases & Signs and Symptoms \\
\hline \multirow[t]{5}{*}{ Protozoa } & $\begin{array}{l}\text { Ichthyophthirius } \\
\text { multifiliis }\end{array}$ & $\begin{array}{l}\text { Ichthyophthiriasis } \\
\text { (White spot disease) }\end{array}$ & $\begin{array}{l}\text { - Presence of whitish cysts on the skin, fins and gills (Sharma et al., 2012). } \\
\text { - Fish exhibits flashing behaviour, swim violently and holds its fin close to } \\
\text { its body (Stoskopf, 2015). } \\
\text { - In severe cases, the skin may detach (Stoskopf, 2015). } \\
\text { - Infected gills become swollen and appear swollen (Stoskopf, 2015). }\end{array}$ \\
\hline & Costianecatrix & Costiasis & 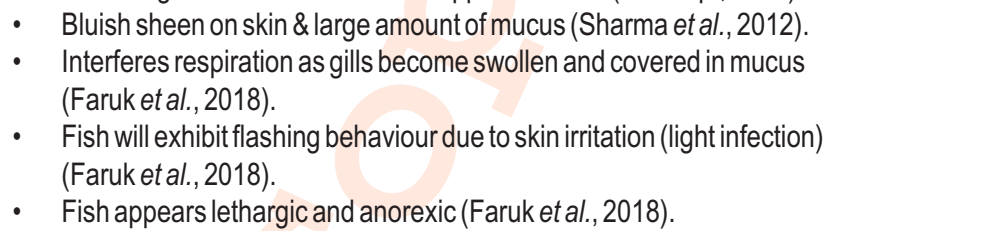 \\
\hline & Trichodina spp. & Trichodiniasis & $\begin{array}{l}\text { - } \text { Bluish sheen on skin \& large amount of mucus (Sharma et al., 2012). } \\
\text { - } \text { Fish exhibits flashing behavior \& becomes lethargic (Sharma et al., 2012). } \\
\text { - } \text { Development of ulcers on skin \& fraying fins (Sharma et al., 2012). } \\
\text { - } \text { Severe respiratory distress (only if gills are involved) (Sharma et al., 2012). } \\
\text { - White patches on the skin and fins (Meyers et al., 2008). }\end{array}$ \\
\hline & $\begin{array}{l}\text { Heteropolaria } \\
\text { colisarum }\end{array}$ & $\begin{array}{l}\text { Epistylis } \\
\text { (Red sore disease) }\end{array}$ & $\begin{array}{l}\text { - Production of excessive external mucus and exhibits flashing. } \\
\text { - Ulcer/ cotton-like growth on skin, scales \& spine causing red lesions } \\
\text { (Sen and Mandal, 2018). }\end{array}$ \\
\hline & $\begin{array}{l}\text { Myxosporidian } \\
\text { parasites }\end{array}$ & $\begin{array}{l}\text { Myxosporidian } \\
\text { infestation }\end{array}$ & $\begin{array}{l}\text { - Cysts on the body, internal tissues and organs (Hoffman, 2019). } \\
\text { - Fish are extremely thin and exhibit abnormal weakness \& falling of scales. }\end{array}$ \\
\hline \multirow[t]{4}{*}{ Fungi } & $\begin{array}{l}\text { Saprolegnia } \\
\text { parasitica }\end{array}$ & $\begin{array}{l}\text { Saprolegniasis } \\
\text { (Cotton wool disease) }\end{array}$ & $\begin{array}{l}\text { - Spoilage of fertilized eggs (El-Atta, 2008). } \\
\text { - Appearance of focal white to brownish cotton-like patches on the skin and/gills. } \\
\text { Presence of lesions of pale foci with peripheral erythema and central zone of } \\
\text { lifted scales (Frasca et al., 2018). }\end{array}$ \\
\hline & $\begin{array}{l}\text { Branchiomyces } \\
\text { sanguinis (in } \\
\text { carps) \& } \\
\text { Branchiomyces } \\
\text { demigrans (in pike } \\
\text { and tench) }\end{array}$ & $\begin{array}{l}\text { Branchiomycosis } \\
\text { (Gill rot) }\end{array}$ & $\begin{array}{l}\text { - } \quad \text { Fish appears lethargic and gulp air at the water surface (Sharma et al., 2012). } \\
\text { - Gills appear striated where the pale areas are infected and dying tissue (Sharma } \\
\text { - } \text { et al., 2012). } \\
\text { - } \quad \text { Mild to moderate infection will have no external signs (Patel et al., 2018). } \\
\text { - } \quad \text { Internal organs may be swollen with white and greyish white sores } \\
\text { (Ameen et al., 2018). }\end{array}$ \\
\hline & Icthyophonus & Icthyophonus disease & - Fish exhibit abnormal swinging movement (Patel et al., 2018). \\
\hline & hoferi & (Swinging d & $\begin{array}{l}\text { - Severely affected organs are liver, spleen, heart, kidney, gonads, brain, gills, muscle } \\
\text { tissue and nerve tissue behind the eye. } \\
\text { - Bulging eyes (due to infection in the brain), loss of colour and weakness (due to } \\
\text { infection in the heart) (Frasca et al., 2018). }\end{array}$ \\
\hline \multirow[t]{4}{*}{ Bacteria } & $\begin{array}{l}\text { Aeromonas, } \\
\text { Pseudomonas } \\
\text { fluorescens, or } \\
\text { Vibrio bacteria }\end{array}$ & Fin and tail rot disease & $\begin{array}{l}\text { - Appearance of a white line on the fin which spreads and gives the fin a frayed } \\
\text { appearance. Eventually, it rots and disintegrates (Kar, 2015). } \\
\text { Occurrence of skin hemorrhages, skin ulcers and blindness (sometimes) } \\
\text { (Mahoney etal., 1973). }\end{array}$ \\
\hline & $\begin{array}{l}\text { Flexibacter } \\
\text { columnaris }\end{array}$ & Ulcer & $\begin{array}{l}\text { - Appearance of raised white plaques often present with reddish peripheral zone that } \\
\text { result in haemorrhagic ulcers (Sen and Mandal, 2018). } \\
\text { - Ulceration of oral mucosa resulting in mouth rot (Declercq et al., 2013). }\end{array}$ \\
\hline & $\begin{array}{l}\text { Aeromonas } \\
\text { bacteria }\end{array}$ & Dropsy & $\begin{array}{l}\text { - } \text { Accumulation of fluid in the body cavity (Kar, 2015). } \\
\text { - } \text { Scale protrusion and exophthalmos. } \\
\text { - } \quad \text { Inflammation of intestines (Song et al., 2017). } \\
\text { - Hemorrhagic ulcers on skin and fins (Kar, 2015). }\end{array}$ \\
\hline & Aeromonas & Eye disease & - Infects cornea and eyeball, optic nerves and the brain (Mishra et al., 2017). \\
\hline
\end{tabular}

To be cont... 


\begin{tabular}{|c|c|c|c|}
\hline Virus & $\begin{array}{l}\text { Rhabdovirus } \\
\text { carpio }\end{array}$ & Spring viremia & $\begin{array}{l}\text { - } \text { Fish turns black and develops lesions on the skin and gills } \\
\text { (LaPatra et al., 2016). } \\
\text { - } \text { Bleeding from scales. } \\
\text { - } \text { Accumulation of fluid in the body. } \\
\text { - } \quad \text { Presence of coelomic distension (dropsy), pale gills, hemorrhages in the gills, skin, } \\
\text { and eye; and a protruding vent with a thick white to yellowish fecal cast } \\
\text { (Petty et al., 2012). } \\
\text { - Dermal lesions and blisters (Haenen et al., 2004). } \\
\text { - Dark pigmentation on infected sites, growth retardation, distended abdomen, } \\
\text { exophthalmia, haemorrhage on the operculum and abdomen } \\
\text { (Lepa, and Siwicki, 2013). }\end{array}$ \\
\hline
\end{tabular}

numerous diseases. Other than infectious disease, fish may also be susceptible to potentially harmful pathogens due to weakening of immune system. Both environmental and stress causing factors are examples of external components which can have dramatic effects on the physiology of fish (Balasch, and Tort, 2019; Magnadottir, 2010; Yap et al., 2011a; Yap et al., 2011b). Hence, treatments are required and often necessary when it comes to curing the fish from various diseases.

Before introducing of phytotherapy to the aquaculture industry, malachite green was one of the most commonly used methods for treating fish diseases. With the increased usage over the years, it was found that malachite green has toxicological effects on the "treated" fish (Ma et al., 2020). Further studies showed that the toxicity and severity of side effects are correlated with increased exposure time and the concentration given (Srivastava et al., 2004). Despite the fact that malachite green could be the most effective treatment, it has been banned in several countries due to the negative effect on fish health. Other than malachite green, peracetic acid (PAA) was also used as a treatment for Ichthyophthirius multifiliis (Sudová et al., 2010). However, peracetic acid had several limitations and disadvantages. The effectiveness of peracetic acid decreased over time due to peroxide degradation (Lindholm-Lehto et al., 2019; Srivastava et al., 2004). In addition, the by-products of degradation, acetic acid and acetate, encouraged the formation of biofilm which in turn became a protection for opportunistic pathogens (Liu, 2016). Most of the time, the adverse impacts of using synthetic medications outweigh the advantages of saving fish. Treatments are usually costly, especially when there is a need for continual treatment with chemicals over a long period of time. It is, therefore, important to explore other choices and techniques that can be used as an alternative to synthetic medications for preventing of fish disease. One such promising methods is phytotherapy.

Role of phytotherapy in aquaculture : Phytotherapy is a medical practice which focus more on traditional approaches rather than modern medication. It highly involves the knowledge and usage of medical herbalism. The application of phytotherapy is rather new to the aquaculture industry but it is slowly being recognised as an alternative to the use of synthetic drugs for treatment (Eirna-Liza et al., 2018). Unlike synthetic chemicals, phytotherapy is a relatively simple and safe method for both affected fish and environment. This is because the treatments or substances used are derived from plants. Most active compounds are extracted from natural sources and they are ecofriendly, farmer-friendly and have little side-effects on fish health. Many researchers have been carried out studies and come to the conclusion that phytotherapy is effective in treating fish disease (Doan et al., 2020; Marco, 2018; Pathirana et al., 2019; Valladão et al., 2015). One common way of treating parasitic fish disease is directly bathing the fish in a medium containing herbs or active compounds extracted from plants. Higher concentration of herbs, within the range of effective concentration, lower than that of lethal concentration $\left(\mathrm{LC}_{50}\right)$, were often reported to yield good efficacy in acute bath treatment of herbs. Acute treatment should be performed within 1-8 hr. Prolonged phytotherapeutic treatment of high concentration may impair fish physiology and behaviour (Doan et al., 2020). Indefinite bath treatment of herbs of lower concentration are also applied to treat the parasitic infections. ElGalil and Aboelhadid (2012) demonstrated that indefinite bath application of $300 \mathrm{mg} \mathrm{l}^{-1}$ (about 200 times less that the reported $\mathrm{LC}_{50}$ of crushed garlic cloves) demonstrated $68 \%$ mitigation of gyrodactylosis in hatchery earthen ponds of tilapia. The other common route of administration is combining plant parts such as leaves, flowers, fruits or using the plant wholly together with fish feeds. This is to ensure that the active ingredients can be fed directly to the aquatic organisms in order to achieve the maximum potential effects. Table 3 shows some of the phytotherapy examples on fish disease.

Apart from treating fish disease, natural products derived from medicinal herbs can be used as a substitution for synthetic growth promoters. Antibiotic growth promoters are commonly used in fish feed to enhance the biological activities. However, extensive and excessive use of growth promoters will do more harm than good. One of the risks associated with the use of synthetic growth promoters is that it can inhibit biogas production 
Table 2 : Different classes of antibiotics used in aquaculture, example of resistant bacteria.

\begin{tabular}{|c|c|c|c|c|}
\hline Class of antibiotics & Mode of action of antibiotics & Example & Resistant bacteria & Isolated from \\
\hline \multirow[t]{2}{*}{ Aminoglycosides } & $\begin{array}{l}\text { Inhibits bacterial protein synthesis } \\
\text { by binding to the } 30 \text { S ribosomal } \\
\text { subunit(Romero et al., 2012). }\end{array}$ & Streptomycin & Edwardsiella ictulari & $\begin{array}{l}\text { Diseased striped catfish(Pangasianodon } \\
\text { hypophthalmus),Vietnam (Dung et al., } \\
\text { 2008). }\end{array}$ \\
\hline & & Kanamycin & $\begin{array}{l}\text { Vibrio } \\
\text { parahaemolyticus }\end{array}$ & $\begin{array}{l}\text { Shrimp farming in Jiangsu, China (He et al., } \\
\text { 2019). }\end{array}$ \\
\hline \multirow[t]{2}{*}{ Amphenicols } & $\begin{array}{l}\text { Inhibits bacterial protein synthesis } \\
\text { by binding to the } 50 \text { S ribosomal } \\
\text { subunit(Swaney etal., 1998). }\end{array}$ & $\begin{array}{l}\text { Chloramph- } \\
\text { enicol }\end{array}$ & Aeromonas spp. & $\begin{array}{l}\text { Integrated fish farms in Osun State, Nigeria } \\
\text { (Samuel et al., 2019). }\end{array}$ \\
\hline & & Florfenicol & $\begin{array}{l}\text { Enterobacterspp. } \\
\text { andPseudomonas } \\
\text { spp. }\end{array}$ & $\begin{array}{l}\text { Freshwater salmon farms, Chile } \\
\text { (Fernández larcón etal., 2010). }\end{array}$ \\
\hline \multirow[t]{4}{*}{ Beta-lactams } & $\begin{array}{l}\text { Inhibits bacterial cell wall synthesis } \\
\text { by blocking enzymes involved for } \\
\text { the synthesis of the peptidoglycan }\end{array}$ & Amoxicillin & Not specified & $\begin{array}{l}50 \% \text { of the surveyed tilapia and catfish farms in } \\
\text { southwestern Vietnam used amoxicillin (Ström } \\
\text { et al., 2019). }\end{array}$ \\
\hline & layer (Romero et al., 2012). & & $\begin{array}{l}\text { Vibrio spp., } \\
\text { Aeromonas spp. } \\
\text { and Edwardsiella } \\
\text { tarda }\end{array}$ & $\begin{array}{l}\text { Different aquaculture settings,Australia } \\
\text { (Akinbowale et al., 2006). }\end{array}$ \\
\hline & & Ampicillin & Vibrio harveyi & $\begin{array}{l}\text { Shrimp farms and coastal waters, Indonesia } \\
\text { (Defoirdt et al., 2011). }\end{array}$ \\
\hline & & Penicillin & $\begin{array}{l}\text { Aeromonas } \\
\text { hydrophila }\end{array}$ & Fish farms in Jiangsu, China (Zhu et al., 2020). \\
\hline Fluoroquinolones & $\begin{array}{l}\text { Inhibits DNA synthesis by causing } \\
\text { double-strand DNA breaks during } \\
\text { DNAreplication (Romero et al., } \\
\text { 2012). }\end{array}$ & Enrofloxacin & $\begin{array}{l}\text { Tenacibaculum } \\
\text { maritimum }\end{array}$ & $\begin{array}{l}\text { Diseased turbot (Scophthalmusmaximus) and } \\
\text { sole(Solea senegalensis), Spainand Portugal } \\
\text { (Avendaño-Herrera et al., 2008). }\end{array}$ \\
\hline \multirow[t]{2}{*}{ Macrolides } & $\begin{array}{l}\text { Inhibits protein synthesis by binding } \\
\text { to the } 30 \text { S subunit of the ribosome } \\
\text { (Romero et al., 2012). }\end{array}$ & Azithromycin & $\begin{array}{l}\text { Aeromonas } \\
\text { hydrophila }\end{array}$ & Fish farms in Jiangsu, China (Zhu et al., 2020). \\
\hline & & Erythromycin & Salmonella spp. & Marketed fish, China (Defoirdt et al., 2011). \\
\hline \multirow[t]{2}{*}{ Nitrofurans } & $\begin{array}{l}\text { Interfere protein synthesis, aerobic } \\
\text { ATP metabolism, nucleotide } \\
\text { synthesis, and cell wall synthesis by } \\
\text { disrupting reactive intermediates that }\end{array}$ & Furazolidone & Vibrio anguillarum & $\begin{array}{l}\text { Diseased sea bass and seabream, Greece } \\
\text { (Yiagnisis et al., 2007). }\end{array}$ \\
\hline & $\begin{array}{l}\text { are formed during reduction process } \\
\text { by bacterial flavoproteins } \\
\text { (Kashanian et al., 2008). }\end{array}$ & Nitrofurantoin & Vibrio harveyi & $\begin{array}{l}\text { Diseased penaeid shrimp, Taiwan (Liu et al., } \\
\text { 1997). }\end{array}$ \\
\hline \multirow[t]{2}{*}{ Quinolones } & $\begin{array}{l}\text { Inhibits DNA synthesis by disrupting } \\
\text { the activity of DNA gyrase which is } \\
\text { involved in the folding and uncoiling }\end{array}$ & Levofloxacin & Escherichia coli & $\begin{array}{l}\text { Fish faecal samples obtained from Rajasthan, } \\
\text { India (Saharan et al., 2019). }\end{array}$ \\
\hline & $\begin{array}{l}\text { of bacterial DNA and the process of } \\
\text { packing nucleotides (Samuelsen } \\
\text { 2006). }\end{array}$ & Oxolinic acid & $\begin{array}{l}\text { Aeromonas spp., } \\
\text { Pseudomonas spp. } \\
\text { and Vibrio spp. }\end{array}$ & $\begin{array}{l}\text { Pond water, pond sediment and } \\
\text { tiger shrimp (Penaeus monodon), } \\
\text { Philippines (Defoirdt et al., 2011). }\end{array}$ \\
\hline \multirow[t]{2}{*}{ Sulphonamides } & $\begin{array}{l}\text { Inhibits the folic acid synthesis } \\
\text { metabolic pathway which leads to } \\
\text { DNA synthesis inhibition } \\
\text { (Romero et al., 2012). }\end{array}$ & $\begin{array}{l}\text { Sulfamethox- } \\
\text { azole (In } \\
\text { combination with } \\
\text { trimethoprim) }\end{array}$ & $\begin{array}{l}\text { Laribacter } \\
\text { hongkongensis }\end{array}$ & $\begin{array}{l}\text { Marketed grass carp (Ctenopharyngodon idella) } \\
\text { in Shenzhen, China }\end{array}$ \\
\hline & & Sulphadiazine & Aeromonasspp. & $\begin{array}{l}\text { Diseased catla (Catla catla),mrigel (Cirrhinus } \\
\text { mrigala) andpunti (Puntius spp.), India (Das } \\
\text { etal., 2009). }\end{array}$ \\
\hline \multirow[t]{2}{*}{ Tetracyclines } & $\begin{array}{l}\text { Inhibits protein synthesis by } \\
\text { binding to the } 30 \text { S subunit of the } \\
\text { ribosome (Romero et al., 2012). }\end{array}$ & Oxytetracycline & $\begin{array}{l}\text { Aeromonas } \\
\text { salmonicida }\end{array}$ & $\begin{array}{l}\text { Atlantic salmon (Salmo salar)culture facilities, } \\
\text { Canada (Defoirdt et al., 2011). }\end{array}$ \\
\hline & & Tetracycline & $\begin{array}{l}\text { Aeromonas } \\
\text { hydrophila }\end{array}$ & $\begin{array}{l}\text { Water from mullet and tilapiafarms, Egypt } \\
\text { (Ishida et al., 2010). }\end{array}$ \\
\hline
\end{tabular}


Table 3 : Some of phytotherapy examples on fish disease

\begin{tabular}{|c|c|c|c|c|}
\hline Pathogen & Host & Plant used & Type/Active compound & Method of administration \\
\hline $\begin{array}{l}\text { Aeromonas hydrophila } \\
\text { (Eirna-Liza et al., 2018) }\end{array}$ & Clariasgariepinus & Allium sativum & Allicin & Orally \\
\hline $\begin{array}{l}\text { Dactylogyrus intermedius (Valladão } \\
\text { et al., 2015; Wang et al., 2008) }\end{array}$ & Carassius auratus & Fructus cnidii & Osthol and isopimpinellin & Water/bath treatment \\
\hline $\begin{array}{l}\text { Gyrodactylus turnbulli (Schelkle et al., } \\
\text { 2013; Valladão et al., 2015) }\end{array}$ & Poecilia reticulata & Allium sativum & Freeze-dried & Water/bath treatment \\
\hline $\begin{array}{l}\text { Ichthyophthirius multifiliis } \\
\text { (Valladão et al., 2015) }\end{array}$ & Ictalurus punctatus & Galla chinensis & Pentagalloylglucose & Water/bath treatment \\
\hline Myxobolus spp. (Valladão et al., 2015) & Diplodus puntazzo & Origanum minutiflorum & Essential oil & Oral \\
\hline Neobenedenia spp. (Militz et al., 2014) & Lates calcarifer & Allium sativum & Allicin & Water/bath treatment \\
\hline
\end{tabular}

Table 4 : Shows examples of beneficial effects of phytotherapy on fish

\begin{tabular}{lll}
\hline Fish & Plant used & Effects \\
\hline Carassius auratus (Chakraborty et al., 2014) & Phyllanthus niruri & Reduced blood glucose level \\
Clarias gariepinus (Abbassa, 2010) & Artemisia cina & Increased growth parameter and immune response \\
Oreochromis aureus (Turan et al., 2007) & Trifolium pratense & Improved growth rate and feed utilization \\
Oreochromis niloticus (Goda, 2008). & Dietary Ginseng Herb & Enhanced growth performance, diet utilization efficiency \\
& Supplementation (Ginsana@ G115) & and haematological indices \\
Oreochromis niloticus (Francis et al., 2001) & Quillaja saponins & Increased growth and reduced metabolic rate \\
\hline
\end{tabular}

(Hao et al., 2014). This is because antibiotics excreted into the environment partially inhibit methanogenesis which decreases the metabolic rate of bacteria to produce biogas (Hao et al., 2014). Thus, people are now more aware of the side effects and consequences of using antibiotics. This is because antibiotics increase the emergence of antibiotic-resistant pathogen and antibiotic residues indirectly discharge through excretion are harmful to the environmental microbial community (Chong et al., 2019). Hence, shifting to a more organic approach is seen to be more promising approach. In order to achieve the same objective, herbal drugs that promote growth are being considered. Herbal drugs are often safer and cheaper compared to synthetic growth promoters. Most importantly, they can achieve similar outcomes in terms of growth performance in aquatic organisms. In other words, farmed fish species can grow healthier and bigger in size by consuming herb-infused feeds. It has been prove that application of phytotherapy in aquaculture has not only resulted in increased growth parameters but also in healthier biological responses. One such study involved feeding Oreochromis niloticus with dietary ginseng herb supplementation (Ginsana® G115) (Goda, 2008). The results showed evidence of enhanced growth performance, diet utilization efficiency and hematological indices (Goda, 2008). Table 4 highlights examples of beneficial effects of phytotherapy on fish.

Plants produce a variety of bioactive compounds to tolerate their habitats, unfavourable weather conditions and pathogenic infections (Varijakzhan et al., 2020). These bioactive compounds are often referred to as secondary metabolites (SMs) alkaloids, essential oils, phenolics, saponins, terpene and carbohydrates synthesised by plants. Although carbohydrates are primary metabolites, they are often incorporated into secondary metabolites by glycosylation (Varijakzhan et al., 2020). Secondary metabolites are able to modulate proteinprotein interactions, such as recognition, binding, catalytic activity and turnover (Hoseinifar et al., 2020). These have given rise to an array of immunoprotective effects for the treatment of non-origin host, which includes: immunostimulants, antibacterial, antiviral, antifungal and anti-stress activities. Various studies have shown the importance of having strong immune system in commercial fish species so that mortalities can be reduced to the lowest during an outbreak of fish disease. These agents have potential to enhance the immune system of host in order to prevent disease infection or for treatment purposes. Nowadays, phytotherapeutic agents are synthesised in combination with natural ingredients, especially with naturally occurring compounds that are found in plants. Immunostimulants are mainly given to fish to enhance the defence mechanism so that fish can become more resistant to disease. Antibacterial agents are used for controlling infectious disease caused by microbes like Aeromonas hydrophila, Vibrio parahaemolyticus and Vibrio damsela. Antiviral agents are used against fish viruses like White spot syndrome virus (WSSV), salmonid rhabdovirus and viral haemorrhagic septicaemia virus (Citarasu, 2010). Antifungal agents are used for treating diseases related to fungal pathogens like Aeromonas hydrophila, Aspergillus flavus and Fusarium oxysporum (Citarasu, 2010). Cultured fish are often affected by ambient abiotic and biotic 
Table 5 : Shows examples of phytotherapeutic agents in aquaculture

\begin{tabular}{|c|c|c|c|c|}
\hline Phytotherapeutic & Plant used & $\begin{array}{l}\text { Type of } \\
\text { organism }\end{array}$ & $\begin{array}{l}\text { Pathogen/ } \\
\text { stressor }\end{array}$ & Effects \\
\hline \multirow[t]{2}{*}{ Immunostimulants } & $\begin{array}{l}\text { Glycyrrhiza glabra } \\
\text { (Edahiro et al., 1991) }\end{array}$ & $\begin{array}{l}\text { Seriola } \\
\text { quinqueradiata }\end{array}$ & $\begin{array}{l}\text { Streptococcus } \\
\text { spp. }\end{array}$ & $\begin{array}{l}\text { Increased protection against streptococcal infection with } \\
\text { increment of } 20 \% \text { survival rate compared to the control group. } \\
\text { Complement activity was significantly higher in the treatment } \\
\text { group. }\end{array}$ \\
\hline & $\begin{array}{l}\text { Helianthus tuberosus } \\
\text { (Ali et al., 2017) }\end{array}$ & Lates calcarifer & $\begin{array}{l}\text { Aeromonas } \\
\text { hydrophila }\end{array}$ & $\begin{array}{l}\text { Increased white blood cell counts, as well as lysozyme activity, } \\
\text { phagocytosis, and respiratory burst activity of leukocytes }\end{array}$ \\
\hline \multirow[t]{2}{*}{ Antibacterial agent } & $\begin{array}{l}\text { Terminalia catappa } \\
\text { (Purivirojkul et al., 2012) }\end{array}$ & Betta splendens & $\begin{array}{l}\text { Aeromonas } \\
\text { hydrophila }\end{array}$ & $\begin{array}{l}\text { Beneficial for improving } \\
\text { survival rates and resistance against } \text { Aeromonas hydrophila }\end{array}$ \\
\hline & $\begin{array}{l}\text { Terminalia catappa } \\
\text { (Chitmanat et al., 2012) }\end{array}$ & $\begin{array}{l}\text { Oreochromis } \\
\text { niloticus }\end{array}$ & $\begin{array}{l}\text { Aeromonas } \\
\text { hydrophila }\end{array}$ & $\begin{array}{l}\text { The Terminalia extract added to the rearing water helps } \\
\text { tocontrol bacterial infection in fish eggs or larval fish in } \\
\text { hatchery which are prone to bacteriainfection. }\end{array}$ \\
\hline \multirow[t]{2}{*}{ Antiviral agent } & $\begin{array}{l}\text { Cynodon dactylon } \\
\text { (Balasubramanian } \\
\text { etal., 2012) }\end{array}$ & Penaeus monodon & $\begin{array}{l}\text { White spot } \\
\text { syndrome virus } \\
\text { (WSSV) }\end{array}$ & Highly effective in preventing WSSV infection with no mortality \\
\hline & $\begin{array}{l}\text { Lonicera japonica } \\
\text { (Liu et al., 2020) }\end{array}$ & $\begin{array}{l}\text { Epinephelus } \\
\text { fuscoguttatus @\& } ~ \\
\text { E. lanceolatus B\& }\end{array}$ & $\begin{array}{l}\text { Grouper } \\
\text { iridovirus }\end{array}$ & $\begin{array}{l}\text { L. japonica exhibited the antiviral activity against grouper } \\
\text { iridovirus infection in a dose-dependent, with above } 90 \% \text { of } \\
\text { inhibition was observed in some of the isolated compounds. }\end{array}$ \\
\hline \multirow[t]{2}{*}{ Antifungal agent } & $\begin{array}{l}\text { Rheum palmatum } \\
\text { (Yao et al., 2017) }\end{array}$ & $\begin{array}{l}\text { Ctenopharyng } \\
\text { odon idella }\end{array}$ & $\begin{array}{l}\text { Saprolegnia } \\
\text { spp. }\end{array}$ & $\begin{array}{l}\text { One week treatment of rhein, a compound isolated from } R \text {. } \\
\text { palmatum, at } 20 \mathrm{mg} \mathrm{I}^{-1} \text { prevented } 93.3 \% \text { of infections by } \\
\text { Saprolegnia in Ctenopharyngodon idella, with recovery rate of } \\
67.7 \% \text { observed in the infected fish. }\end{array}$ \\
\hline & $\begin{array}{l}\text { Terminalia catappa } \\
\text { (Chitmanat et al., 2012) }\end{array}$ & $\begin{array}{l}\text { Oreochromis } \\
\text { niloticus }\end{array}$ & Not specified & Reduced fungal infection in tilapia eggs \\
\hline \multirow[t]{2}{*}{ Anti-stress agent } & $\begin{array}{l}\text { Moringa oleifera } \\
\text { (Kaleo et al., 2019) }\end{array}$ & $\begin{array}{l}\text { Macrobrachium } \\
\text { rosenbergii }\end{array}$ & $\begin{array}{l}\text { Ammonia } \\
\text { stress }\end{array}$ & $\begin{array}{l}0.5 \% \text { oral supplementation of } M \text {. oleiferaleaf extract mitigated } \\
\text { physiological changes of prawns caused by } 72 \text { hours of } \\
\text { ammonia stress test. }\end{array}$ \\
\hline & $\begin{array}{l}\text { Toona sinensis } \\
\text { (Hsieh et al., 2008) }\end{array}$ & $\begin{array}{l}\text { Litopenaeus } \\
\text { vannamei }\end{array}$ & $\begin{array}{l}\text { Vibrio } \\
\text { alginolyticus }\end{array}$ & $\begin{array}{l}\text { Improved the biochemical, immunological and hematological } \\
\text { parameters during stress conditions }\end{array}$ \\
\hline
\end{tabular}

stressors. These stressors can affect metabolic state and eventually compromise the health status. Anti-stress agents are mainly used to reduce the overall stress levels of fish (Hoseinifar et al., 2020).

On account of great variations among the reported studies, in term of phytotherapeutic sources, treatment protocol, host and target pathogens, comparison between these data in the literature is complicated (Valladão et al. 2015). Table 5 provides some examples of bioactivity of phytotherapeutic agents in aquaculture.

Limitation and prospects : Various parts of medicinal plants have been used as an age-old practice to treat diseases; however, they were in the form of unrefined extracts. Modern drugs are developed from these extracts after substantial investigation of their bioactive mechanisms of action (which is often unknown), therapeutic and toxic effects, and also proper standardisation in clinical trials. Investigation on the biological activity and medicinal application of plants in combating diseases affecting the aquaculture industry is meagre. On the other hand, most studies conducted on their effectiveness are based on in- vitro testing or under laboratory conditions. Further, practical studies are required to enable replacement of current treatments. Hence, more serious investigations are required to harness the therapeutic properties and herbal formulations for drug development of medicinal plants to combat disease problems in aquaculture. Studies carried out on phytotherapy of human and other animal diseases should also be taken advantage of by the aquaculture sector to extract suitable principles that can be applied in combating the diseases of fisheries world.

Another challenge that the industry has to tackle is the increasing commercial demand for wild-sourced plant drugs globally is occurring at the expense of rapid deforestation and degradation of species-rich forest ecosystems (Bodeker, 2003). A portion of medicinal plants suffer from resource destruction and are threatened or endangered. Those who are involved in herbal medicine production, trade and utilisation must adhere to the conservation of biological diversity so that sustainable use of its components and the benefits arising from the utilization of these precious resources can be acquired by all (Janke, 2018). Government organisations should emphasise on encouraging private companies to systematically cultivate medicinal herbs by providing positive support and incentives. 
Another subject to consider is the ethical aspect of conducting research on animals. There is a risk involved of harming animals in aquaculture to further study the benefits of phytotherapy in the industry. This risk or the impact of risk can be reduced in several ways: for instance, a good study design will help to utilise minimum number of animals required for data collection. However, a sufficient number must be used to attain precise analysis and results, thus, preventing unnecessary repetition of experiments and the consequent need to use more animals (Ghasemi and Dehpour, 2009). Next, the researchers should work towards minimising pain and distress in the animals tested. Anaesthetics and analgesics should be administered whenever necessary during the experiments. Multiple surgeries on same animal must receive special approval from an animal care committee (Ghasemi and Dehpour, 2009).

Finally, with the success of previous research showing significant results with the experimentation of herbal drugs in aquaculture, it has raised the interest of exploring the possibilities of replacing modern synthetic chemicals with traditional naturally compounds. This will lead more researchers to conduct experiments and evaluate the potential and maximise the benefits of natural products.

\section{Acknowledgments}

This work was supported by the Fundamental Research Grant Scheme (FRGS; project code: FRGS/1/2015/SG03/ UPM/02/4) Long Term Research Grant Scheme (LRGS; project code: LRGS/1/2019/UPM/1) and the SATREPS COSMOSMOHE project, offered by the Ministry of Higher Education Malaysia.

\section{References}

Abbassa, A.H.: Study on the effect of wormseed plants; Artemisia cina L. and chamomile; Matricaria chamomilla L. on growth parameters and immune response of African catfish, Clarias gariepinus. J. Fish Int., 5, 1-7 (2010).

Akinbowale, O.L., H. Peng and M.D. Barton: Antimicrobial resistance in bacteria isolated from aquaculture sources in Australia. J. Appl. Microbiol., 100, 1103-1113 (2006).

Ali, S.S.R., K. Ambasankar, M.S. Musthafa and R. Harikrishnan: Jerusalem artichoke enriched diet on growth performance, immuno-hematological changes and disease resistance against Aeromonas hydrophila in Asian seabass (Lates calcarifer). Fish Shellfish Immun., 70, 335-342 (2017).

Ameen, F., K. Al-Niaeem, M.M. Taher and F.A. Sultan: Potential of plant extracts to inhibit the Ichthyophonus sp. infection in blue tilapia: A preliminary study in vitro. Nat.IAcad. Sci. Lett., 41, 129-132 (2018).

Assefa, A. and F. Abunna: Maintenance of fish health in aquaculture: Review of epidemiological approaches for prevention and control of infectious disease of fish. Vet. Med. Int., 2018, 1-10 (2018).

Avendaño-Herrera, R., S. Núñez, J.L. Barja and A.E. Toranzo: Evolution of drug resistance and minimum inhibitory concentration to enrofloxacin in Tenacibaculum maritimum strains isolated in fish farms. Aquac. Int., 16, 1-11 (2008).

Balasch, J.C. and L. Tort: Netting the stress responses in fish. Front. Endocrino.I (Lausanne), 10, 1-12 (2019).

Balasubramanian, G., M. Sarathi, C. Venkatesan, J. Thomas and A.S.S. Hameed: Oral administration of antiviral plant extract of Cynodon dactylon on a large scale production against White spot syndrome virus (WSSV) in Penaeus monodon. Aquaculture, 279, 2-5 (2008).

Bassetti, M., D.R. Giacobbe, A. Vena and A. Brink: Challenges and research priorities to progress the impact of antimicrobial stewardship. Drugs Context, 8, 212600 (2019).

Begum, S., M. Salauddin, M.K. Hossain and M.D. Begum: Antibiogram study of bacterial pathogen from tilapia fish in Bangladesh. TURJAF, 7, 658-664 (2019).

Bodeker, G.: Medicinal plants for forest conservation and health care. Rome: FAO (2003).

Brummett, R.E., A. Alvial, F. Kibenge, J. Forster, J.M. Burgos, R. Ibarra, S. St-Hilaire, G.C. Chamberlain, D.V. Lightner, L.V. Khoa and N.V. Hao: Reducing disease risk in aquaculture. World Bank Report Number 88257-GLB (2014).

Cabello, F.C.: Heavy use of prophylactic antibiotics in aquaculture: A growing problem for human and animal health and for the environment. Environ Microbiol., 8, 1137-1144 (2006).

Chakraborty, S.B., P. Horn and C. Hancz: Application of phytochemicals as growth-promoters and endocrine modulators in fish culture. Rev. Aquacul., 6, 1-19(2014).

Chitmanat, C., K. Tongdonmuan, P. Khanom, P. Pachontis and W. Nunsong: Antiparasitic, antibacterial and antifungal activities derived from a Terminalia catappa solution against some tilapia (Oreochromis niloticus) pathogens. Acta Hortic., 678, 179-182 (2003).

Chong, W.W., S.Y.C. Lim, K.S. Lai and J.Y. Loh: In vitro antimicrobial assessment of lactic acid bacteria isolated from freshwater fishes. AsPac J. Mol. Biol. Biotechnol., 27,18-25 (2019).

Chong, C. and C. Low: Synthetic antibody: Prospects in aquaculture biosecurity. Fish Shellfish Immunol., 86, 361-367 (2019).

Chong, C.M. and A. Maha: Fish and Crustaceans: Immune System, Vaccine Development and Implications. In: Perspective of Fisheries and Aquaculture in Malaysia (Eds.: S. M. Nurul Amin, M.S. Kamarudin, A. Arshad, N. Romano). Universiti Putra Malaysia Press, Selangor, p. 188 (2014).

Citarasu, T.: Herbal biomedicines: A new opportunity for aquaculture industry. Aquac. Int., 18, 403-414 (2010).

Das, A., D. Saha and J. Pal: Antimicrobial resistance and in vitro gene transfer in bacteria isolated from the ulcers of EUS affected fish in India. Lett. Appl. Microbiol., 49, 497-502 (2009).

Dauda, A.B., N. Romano, M. Ebrahimi, J.C. Teh, A. Ajadi, C.M. Chong, M. Karim, I. Natrah, and M.S. Kamarudin: Influence of carbon/nitrogen ratios on biofloc production and biochemical composition and subsequent effects on the growth, physiological status and disease resistance of African catfish (Clarias gariepinus) cultured in glycerol-based biofloc systems. Aquaculture, 483, 120-130 (2018).

Declercq, A.M., F. Haesebrouck, W. Van den Broeck, P. Bossier and A. Decostere: Columnaris disease in fish: A review with emphasis on bacterium-host interactions. Vet. Res., 44, 1-17 (2013).

Defoirdt, T., P. Sorgeloos and P. Bossier: Alternatives to antibiotics for the control of bacterial disease in aquaculture. Curr. Opin. Microbiol., 14, 251-258 (2011).

Doan, H.V., E. Soltani, J. Ingelbrecht and M. Soltani: Medicinal herbs and 
plants: potential treatment of monogenean infections in fish. Rev. Fish. Sci. Aquac., 28, 1-23 (2020).

Dung, T.T., F. Haesebrouck, N.A. Tuan, P. Sorgeloos, M. Baele and A. Decostere: Antimicrobial susceptibility pattern of Edwardsiella ictaluri isolates from natural outbreaks of bacillary necrosis of Pangasianodon hypophthalmus in Vietnam. Microb. Drug Resist., 14, 311-316 (2008).

Ebrahimi, M., N.H. Daeman, C.M. Chong, A. Karami, V. Kumar, S.H. Hoseinifar and N. Romano: Comparing the effects of different dietary organic acids on the growth, intestinal short-chain fatty acids, and liver histopathology of red hybrid tilapia (Oreochromis sp.) and potential use of these as preservatives. Fish Physiol. Biochem., 43, 1195-1207 (2017).

Edahiro, T., M. Hamaguchi and R. Kusuda: Suppressive effect of glycyrrhizin against streptococcal infection promoted by feeding oxidized lipids to yellowtail Seriola quinqueradiata. Aquac Sci., 39, 21-7 (1991).

Eirna-Liza, N., H.A. Hassim, C.C. Min, F. Syukri and M. Karim: The duration of protection conferred by garlic on African catfish (Clarias gariepinus) against Aeromonas hydrophila. J. Aquac. Res. Devel., 9, 2 (2018).

El-Atta, M.E.A.: Saprolegniosis in freshwater cultured Tilapia nilotica (Oreochromis niloticus) and trial for control by using Bafry D50/500. I. S. T.A. 8., 2008, 1403-1418 (2008).

El-Galil, M.A.A. and S.M. Aboelhadid: Trials for the control of trichodinosis and gyrodactylosis in hatchery reared Oreochromis niloticus fries by using garlic. Vet. Parasitol., 185, 57-63 (2012).

Falzon, C.C. and A. Balabanova: Phytotherapy: An introduction to herbal medicine. Prim. Care., 44, 217-227 (2017).

FAO: FAO yearbook. Fishery and Aquaculture Statistics 2017. Rome (2019).

FAO: The State of World Fisheries and Aquaculture 2018 - Meeting the Sustainable Development Goals. Rome (2018).

Faruk, M.A.R.: Fish Parasite: Infectious diseases associated with fish parasite. In: Seafood Safety and Quality (Eds: M.L. Bari and K. Yamazaki). CRC Press, London, pp. 154-176 (2018).

Fernández-Alarcón, C., C.D. Miranda, R.S. Singer, Y. Lopez, R. Rojas, H. Bello, M. Domínguez and G. González-Rocha: Detection of the floR gene in a diversity of florfenicol resistant gram-negative bacilli from freshwater salmon farms in Chile. Zoonoses Public Hith., 57 , 181-188 (2010).

Francis, G., H.P.S. Makkar and K. Becker: Effects of Quillaja saponins on growth, metabolism, egg production and muscle cholesterol in individually reared Nile tilapia (Oreochromis niloticus). Comp. Biochem. Physiol. Part C Toxicol. Pharmacol., 129,105-114 (2001).

Frasca Jr, S., J.C. Wolf, M.J. Kinsel, A.C. Camus and E.D. Lombardini: Osteichthyes. In: Pathology of Wildlife and Zoo Animals (Eds: K.A. Terio, D.M. and J.S. Leger). Academic Press, London, pp. 9531001 (2018).

Ghasemi, M. and A.R. Dehpour: Ethical considerations in animal studies. J. Med. Ethics Hist. Med., 2, 12 (2009).

Goda, A.M.S.: Effect of dietary Ginseng herb (Ginsana® G115) supplementation on growth, feed utilization, and hematological indices of Nile Tilapia, Oreochromis niloticus (L.), fingerlings. J. WorldAquac. Soc., 39, 205-214 (2008).

Haenen, O.L.M., K. Way, S.M. Bergmann and E. Ariel: The emergence of koi herpesvirus and its significance to European aquaculture. Eur. Assoc. Fish Pathol., 24, 293-307 (2004).
Hao, H., G. Cheng, Z. Iqbal, X. Ai, H.I. Hussain, L. Huang, M. Dai, Y. Wang, Z. Liu and Z. Yuan: Benefits and risks of antimicrobial use in food-producing animals. Front. Microbiol., 5, 288 (2014).

He, Y., S. Wang, J. Zhang, X. Zhang, F. Sun and B. He: Integrative and conjugative elements-positive Vibrio parahaemolyticus isolated from aquaculture shrimp in Jiangsu, China. Front. Microbiol., 10, 1574 (2019).

Hoffman, G.L.: Parasites of North American freshwater fishes. $2^{\text {nd }}$ Edn., Cornell University Press. London (2019).

Hoseinifar, S.H., Y.Z. Sun, Z. Zhou, H. Van Doan, S.J. Davies and R. Harikrishnan: Boosting immune function and disease bio-control through environment-friendly and sustainable approaches in finfish aquaculture: herbal therapy scenarios. Rev. Fish. Sci. Aquac., 28, 303-321 (2020).

Hsieh, T.J., J.C. Wang, C.Y. Hu, C.T. Li, C.M. Kuo and S.L. Hsieh: Effects of Rutin from Toona sinensis on the immune and physiological responses of white shrimp (Litopenaeus vannamei) under Vibrio alginolyticus challenge. Fish Shellfish Immunol., 25, 581-588 (2008).

Ishida, Y., A.M. Ahmed, N.B. Mahfouz, T. Kimura, S.A. El-Khodery, A.A. Moawad and T. Shimamoto: Molecular analysis of antimicrobial resistance in Gram-negative bacteria isolated from fish farms in Egypt. J. Vet. Med. Sci., 72, 727-734 (2010).

Janke, T.: From Smokebush to Spinifex: Indigenous traditional knowledge and the commercialisation of plants. Int. Jl. Rural Law P., 1, ID-5713 (2018).

Kaleo, I.V., Q. Gao, B. Liu, C. Sun, Q. Zhou, H. Zhang, F. Shan, Z. Xiong, L. Bo and C. Song: Effects of Moringa oleifera leaf extract on growth performance, physiological and immune response, and related immune gene expression of Macrobrachium rosenbergii with Vibrio anguillarum and ammonia stress. Fish Shellfish Immunol., 89, 603-613 (2019).

Kar, D.: Epizootic Ulcerative Fish Disease Syndrome. Academic Press, San Diego, CA, USA(2015).

Karunasagar, I., R. Pai, G.R. Malathi and I. Karunasagar: Mass mortality of Penaeus monodon larvae due to antibiotic-resistant Vibrio harveyi infection. Aquaculture,128, 203-209 (1994).

Kashanian, J., P. Hakimian, M. Blute Jr, J. Wong, H. Khanna, G. Wise, and R. Shabsigh: Nitrofurantoin: The return of an old friend in the wake of growing resistance. BJU Int., 102,1634-1637 (2008).

LaPatra, S., E. Misk, L. Al-Hussinee and J.S. Lumsden: Rhabdoviruses of fish. In: Aquaculture Virology (Eds.: F.S.B. Kibenge and M.G. Godoy). Academic Press, London, pp. 267-297 (2016).

Lepa, A. and A.K. Siwicki: Fish herpesvirus diseases: A short review of current knowledge. Acta Vet. Brno, 81, 383-389 (2013).

Lindholm-Lehto, P.C., S. Suurnäkki, J.T. Pulkkinen, S.L. Aalto, M. Tiirola and J. Vielma: Effect of peracetic acid on levels of geosmin, 2methylisoborneol, and their potential producers in a recirculating aquaculture system for rearing rainbow trout (Oncorhynchus mykiss). Aquacult. Eng., 85, 56-64 (2019).

Liu, M., Q. Yu, Y. Yi, H. Xiao, D.F. Putra, K. Ke, Q. Zhang and P. Li: Antiviral activities of Lonicera japonica Thunb. components against grouper iridovirus in-vitro and in-vivo. Aquaculture, 519, 734-882 (2020).

Liu, P.C., K.K. Lu and S.N. Chen: Susceptibility of different isolates of Vibrio harveyi to antibodies. Microbios, 91, 368-369 (1997).

Ma, R., W. Fang, H. Zhang, J. Sun, H. Su, T. Chen and K. Hu: Transcriptome analysis of zebra fish (Danio rerio) eggs following treatment with malachite green. Aquaculture, 514, 734500 (2020). 
Magnadottir, B.: Immunological control of fish diseases. Mar. Biotechnol., 12, 361-379 (2010).

Mahizan, N.A., S.K. Yang, C.L. Moo, A.A.L. Song, C.M. Chong, C.W. Chong, A. Abushelaibi, S.H.E. Lim and K.S. Lai: Terpene derivatives as a potential agent against antimicrobial resistance (amr) pathogens. Molecules, 24, 2631 (2019).

Mahoney, J.B., F.H. Midlige and D.G. Deuel: A fin rot disease of marine and euryhaline fishes in the New York Bight. Trans. Am. Fish. Soc., 102, 596-605 (1973).

Masduki, F., C.C. Min and M. Karim: Developments of lactic acid bacteria as probiotic for bacterial diseases control in aquaculture. P. J. S.R. R., 4, 41-53 (2018).

Marco, T.D.: Current knowledge on essential oils as alternative treatment against fish parasites. Aquat. Living Resour., 31, 13 (2018).

Meyers, T., T. Burton, C. Bentz and N. Starkey: Common diseases of wild and cultured fishes in Alaska. Fish Pathology Laboratories, Alaska Department of Fish and Game. Anchorage, Alaska, USA (2008).

Militz, T.A., P.C. Southgate, A.G. Carton and K.S. Hutson: Efficacy of garlic (Allium sativum) extract applied as a therapeutic immersion treatment for Neobenedenia sp. management in aquaculture. J. Fish Dis., 37, 451-61 (2014).

Mishra, S.S., D. Rakesh, M. Dhiman, P. Choudhary, J. Debbarma, S.N. Sahoo, A. Barua, B.S. Giri, R. Ramesh, K. Ananda and C.K. Mishra: Present status of fish disease management in freshwater aquaculture in India: state-of the-art-review. J. Aquac. Fisheries, 1, 1-9 (2017).

Moo, C.L., S.K. Yang, K. Yusoff, M. Ajat, W. Thomas, A. Abushelaibi, S.H. E. Lim and K.S. Lai: Mechanisms of antimicrobial resistance (AMR) and alternative approaches to overcome AMR. Curr. Drug Discov. Tech., 17, 430-447 (2020).

Pathirana, H.N.K.S., S.H.M.P. Wimalasena, B.C.J. De Silva, S. Hossain, and G.J. Heo: Antibacterial activity of cinnamon (Cinnamomum zeylanicum) essential oil and cinnamaldehyde against fish pathogenic bacteria isolated from cultured olive flounder Paralichthys olivaceus. Indian J. Fish, 66, 86-92 (2019).

Patel, A.S., S.J. Patel, A.R. Bariya, B.A. Pata and S.N. Ghodasara: Fungal diseases of fish:Areview. J. Vet. Sci. Res, 3, 1-5 (2018).

Petty, B.D., A.C. Riggs, R. Klinger, R.P. Yanong and R. Francis-Floyd: Spring viremia of carp. Fact Sheet VM-142. University of Florida Cooperative Extension Service, Gainesville, FL, University of Florida (2012).

Purivirojkul, W.: Potential application of extracts from Indian almond (Terminalia catappa Linn.) leaves in Siamese fighting fish (Betta splendens Regan) culture. Commun. Agric. Appl. Biol. Sci., 77, 439-448 (2012).

Romano, N., N. Kanmani, M. Ebrahimi, C.M. Chong, J.C. Teh, S.H. Hoseinifar, S.N. Amin, M.S. Kamarudin and V. Kumar: Combination of dietary pre-gelatinized starch and isomaltooligosaccharides improved pellet characteristics, subsequent feeding efficiencies and physiological status in African catfish, Clarias gariepinus, juveniles. Aquaculture, 484, 293-302 (2018)

Romano, N., W. Simon, M. Ebrahimi, A.H. Fadel, C.M. Chong and M.S. Kamarudin: Dietary sodium citrate improved oxidative stability in red hybrid tilapia (Oreochromis sp.) but reduced growth, health status, intestinal short chain fatty acids and induced liver damage. Aquaculture, 458, 170-176 (2016).

Romero, J., C.G. Feijoó and P. Navarrete: Antibiotics in aquaculture-use, abuse and alternatives. In: Health and environment in aquaculture (Eds.: E.D. Carvalho, G.S. David and R.J. Silva). InTech, Rijeka, Crotia (2012).

Saharan, V.V., P. Verma and A.P. Singh: High prevalence of antimicrobial resistance in Escherichia coli, Salmonella spp. and Staphylococcus aureus isolated from fish samples in India. Aquac. Res., 00,1-11 (2019).

Said, B.H., J.T.R. Maria, P. Leonardo, C.D. Danielle, M.I. Carlos and A.E. Maria: Fish pathogen bacteria: Adhesion, parameters influencing virulence and interaction with host cells. Fish Shellfish. Immun., 80, 550-562 (2018).

Samuel, B.A., M.C. Igboama and I.I. Olufade: Impact of integrated fish farming on antimicrobial resistant bacteria in pond environments in Osun state, Nigeria. Int. J. Curr. Microbiol. App. Sci, 8, 2427-2434 (2019).

Samuelsen, O.B.: Pharmacokinetics of quinolones in fish: A review. Aquaculture, 255, 55-75(2006).

Schelkle, B., D. Snellgrove and J. Cable: In vitro and in vivo efficacy of garlic compounds against Gyrodactylus turnbulli infecting the guppy (Poecilia reticulata). Vet. Parasitol., 198, 96-101 (2013).

Sen, K. and R. Mandal: Fresh-water fish diseases in west Bengal, India. Int. J. Fish. Aquat. Stud., 6, 356-362 (2018).

Sharma, M., A.B. Shrivastav, Y.P. Sahni and G. Pandey: Overviews of the treatment and control of common fish diseases. Int. Res. J. Pharm., 3, 123-127 (2012).

Song, X., X. Hu, B. Sun, Y. Bo, K. Wu, L. Xiao and C. Gong: A transcriptome analysis focusing on inflammation-related genes of grass carp intestines following infection with Aeromonas hydrophila. Sci. Rep., 7, 40777 (2017).

Srivastava, S., R. Sinha and D. Roy: Toxicological effects of malachite green. Aquat. Toxicol. Amst. Neth., 66, 319-329 (2004).

Stoskopf, M.K.: Biology and management of laboratory fishes. In: Laboratory Animal Medicine (Eds.: J. G. Fox, L. C. Anderson, G. M. Otto, K.R. Pritchett-Corning and M.T. Whary). Academic Press, London, pp. 1063-1086 (2015).

Ström, G. H., H. Björklund, A. C. Barnes, C. T.,Da, N. H. Y.,Nhi, T. T. Lan, T.T., U. Magnusson, A. Norman Haldén and S. Boqvist: Antibiotic use by small-scale farmers for freshwater aquaculture in the Upper Mekong Delta, Vietnam. J. Aquat. Anim. Hlth., 31, 290-298 (2019).

Sudová, E., D.L. Straus, A. Wienke and T. Meinelt: Evaluation of continuous 4-day exposure to peracetic acid as a treatment for Ichthyophthirius multifiliis. Parasitol. Res., 106, 539-542 (2010)

Swaney, S.M., H. Aoki, M.C. Ganoza and D.L. Shinabarger: The oxazolidinone linezolid inhibits initiation of protein synthesis in bacteria. Antimicrob. Agents Chemother., 42, 3251-3255 (1998).

Turan, F., M. Gurlek and D. Yaglioglu: Dietary red clover (Trifolium pratense) on growth performance of common carp (Cyprinus carpio). J. Anim. Vet. Adv., 6, 1429-1433 (2007).

Valladão, G.M.R., S.U. Gallani and F. Pilarski: Phytotherapy as an alternative for treating fish disease. J. Vet. Pharmacol. Ther., 38, 417-28 (2015)

Varijakzhan, D., C.M. Chong, A. Abushelaibi, K.S. Lai and S.H.E. Lim: Middle eastern plant extracts: an alternative to modern medicine problems. Molecules, 25, 1126 (2020).

Wang, G., Z. Zhou, C. Cheng, J. Yao and Z. Yang: Osthol and isopimpinellin from Fructus cnidii for the control of Dactylogyrus intermedius in Carassius auratus. Vet. Parasitol., 158, 144-151 (2008).

Whittington, R.J., M. Crockford, D. Jordan and B. Jones: Herpesvirus that caused epizootic mortality in 1995 and 1998 in pilchard, 
Sardinops sagax neopilchardus (Steindachner), in Australia is now endemic. J. Fish Dis., 31, 97-105 (2008).

Yao, J.Y., L.Y. Lin, X.M. Yuan, W.L. Ying, Y. Xu, X.Y. Pan, G.J. Hao, J.Y. Shen, J.C. Wu, T. Ye and P.H. Ge: Antifungal activity of rhein and aloe-emodin from Rheum palmatum on fish pathogenic Saprolegnia sp. J. World Aquac. Soc., 48, 137-144 (2017).

Yap, C.K., C.M. Chong and S.G. Tan: Allozyme polymorphisms in horseshoe crabs, Carcinoscorpius rotundicauda, collected from polluted and unpolluted intertidal areas in Peninsular Malaysia. Environ. Monit. Assess., 174 , 389-400 (2011).
Yap, C.K., C.M. Chong and S.G. Tan: Lactate dehydrogenase in guppy fish (Poecilia reticulata) as a biomarker for heavy-metal pollution in freshwater ecosystems. J. S. S. M., 6, 240-246 (2011).

Yiagnisis, M., I.N. Vatsos, C. Kyriakou and M. Alexis: First report of Vibrio anguillarum isolation from diseased big scale sand smelt, Atherina boyeri Risso 1810, in Limnos, Greece. Bull. Eur. Ass. Fish Pathol., 27,61-69 (2007).

Zhu, W., S. Zhou and W. Chu: Comparative proteomic analysis of sensitive and multi-drug resistant Aeromonas hydrophila isolated from diseased fish. Microb. Pathog., 139, 103930 (2020). 